\title{
A Review on the Transformation of Furfural Residue for Value-Added Products
}

\author{
Yong Sun ${ }^{1,2, *}$, Zhi Wang ${ }^{1,2}{ }^{(0)}$, Yuyingnan Liu ${ }^{1}$, Xianghui Meng ${ }^{1}$, Jingbo $Q u^{1}$, Changyu Liu ${ }^{1}$ \\ and $\operatorname{Bin} Q \mathbf{u}^{1}$ \\ 1 Department of Agriculture Biological Environment and Energy Engineering, School of Engineering, \\ Northeast Agriculture University, Harbin 150030, China; wangzhi@neau.edu.cn (Z.W.); \\ tomtom12138@outlook.com (Y.L.); mxh15951003375@163.com (X.M.); ququjingbo@126.com (J.Q.); \\ lcy57649976@163.com (C.L.); qubin@neau.edu.cn (B.Q.) \\ 2 Key Laboratory of Renewable Resources Utilization Technology and Equipment for Cold Region Agriculture \\ in Heilongiiang Province, Harbin 150030, China \\ * Correspondence: sunyong740731@163.com or sunyong@neau.edu.cn; Tel./Fax: +86-451-5519-1670
}

Received: 19 November 2019; Accepted: 18 December 2019; Published: 19 December 2019

\begin{abstract}
As a by-product of lignocellulosic depolymerization for furfural production, furfural residue (FR) is composed of residual cellulose, lignin, humic acid, and other small amounts of materials, which have high reuse value. However, due to the limitation of furfural production scale and production technology, the treatment of FR has many problems such as high yield, concentrated stacking, strong acidity, and difficult degradation. This leads to the limited treatment methods and high treatment cost of furfural residue. At present, most of the furfural enterprises can only be piled up at will, buried in soil, or directly burned. The air, soil, and rivers are polluted and the ecological balance is destroyed. Therefore, how to deal with furfural residue reasonably needs to be solved. In this review, value-added products for furfural residue conversion are described in detail in the fields of soil culture, catalytic hydrolysis, thermal decomposition, and porous adsorption. The future studies reporting the FR to convert value-added products could find guidance from this review to achieve specific goals.
\end{abstract}

Keywords: furfural residue; value-added products; waste utilization; lignocellulose

\section{Introduction}

Furfural, which is also known as furan formaldehyde $\left(\mathrm{C}_{5} \mathrm{H}_{4} \mathrm{O}_{2}\right)$, is a high-value platform molecular chemical in the separation and synthesis industry, which can be obtained by high temperature depolymerization and dehydration distillation of lignocellulose like corncob in acidic medium [1]. The industrial process (General production conditions: $160-180{ }^{\circ} \mathrm{C}, 0.8-1.0 \mathrm{MPa}$, and $10 \%$ sulfuric acid) for furfural production can break down the complex dense structure of lignocellulose, decompose unstable hemicellulose into pentosan, and further generating furfural (as shown in Figure 1). Subsequently, rough furfural emerges with hot steam, which is dehydrated and distilled to produce the refined furfural [2]. The remaining solid waste after furfural production is the FR. 


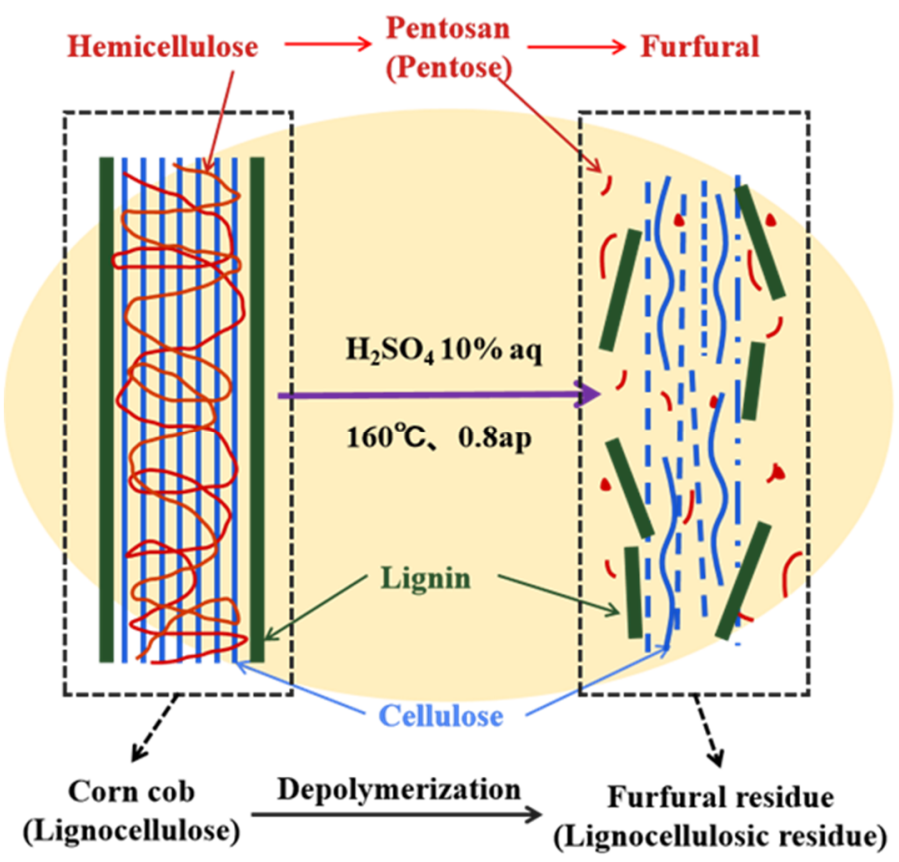

Figure 1. Schematic diagram of furfural production and FR formation.

As a kind of intermediate for the production of various chemical products, furfural has high commercial value and yield demand. However, no direct synthetic method has been found, which can only be extracted by polymerization of lignocellulose. Previous studies have shown that the conversion rate of most furfural factories is only $50 \%$ to $60 \%$ [3]. As such, one ton of furfural product will produce 10 to 15 tons of underutilized FR. There are more than 200 furfural factories in China [4], according to the annual furfural capacity of 1000 tons per furfural factory. The annual FR output can reach 2 million to 3 million tons. The accumulation of FR occupies a large amount of land and even causes a series of environmental problems such as air, soil, and river pollution [5]. Therefore, how to deal with FR reasonably, and even further reuse it to transform value-added products, is key to achieve non-polluting and high-efficiency production of furfural. This is an urgent problem to solve in industrial production of furfural. For this, this review summarized the different value-added product transformation of furfural from four main research aspects, providing guidance for the correct treatment of FR in practical application.

\section{Characteristics and Value-Added Products of FR}

The pentose for furfural production usually comes from hemicelluloses of agricultural waste (e.g., corn cobs, straws, and rice husks) and the residue produced by the furfural process is characterized by high salinity, strong acidity, and difficult degradation, which makes it difficult to treat.

As shown in Figure 2, the composition of FR can be observed where most of the hemicellulose for the corn cob is consumed during the furfural production process, and the remaining part exists in the form of short-chain pentose (2.18\%). The rest of FR mainly consists of lignin $(40.23 \%)$, cellulose $(38.06 \%)$, humic acid $(12.35 \%)$, trace elements $(2.28 \%)$, acetic acid $(3.55 \%)$, and sulfate ion $(1.35 \%)$. Due to the high temperature catalytic depolymerization and the hydrolysis of unstable hemicellulose, the hydrogen bonds, covalent bonds, and van der Waals forces between cellulose, hemicellulose, and lignin in lignocellulose are broken, which make FR present fluffiness and porous characteristics. Therefore, previous scholars have conducted in-depth studies in different directions on the characteristics of FR, including four research directions of soil cultivation, catalytic hydrolysis, high temperature pyrolysis, and porous adsorption [6]. A variety of value-added products have been developed in different research directions (Figure 3). 


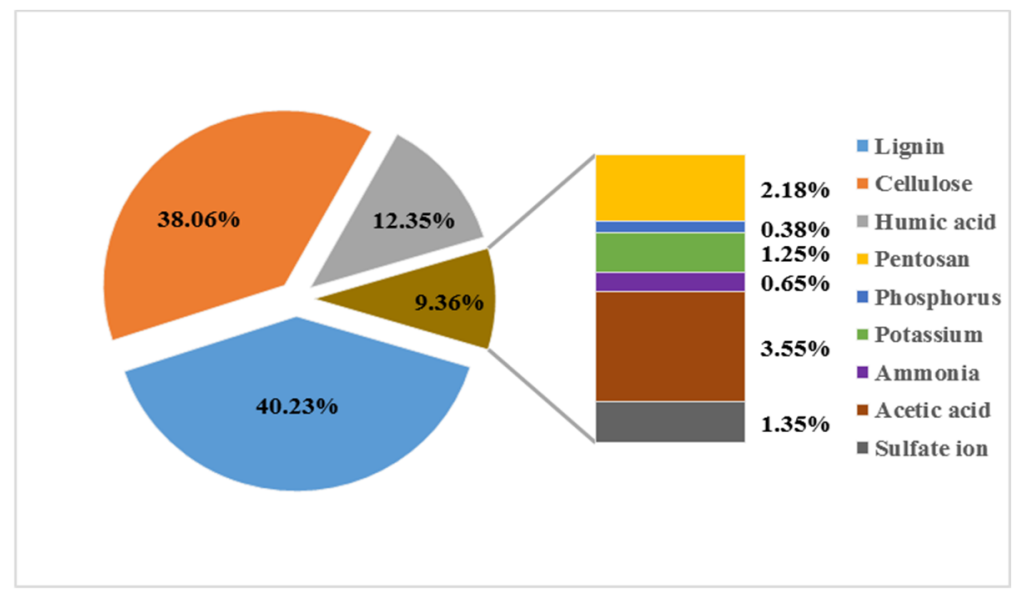

Figure 2. The composition of FR from the corn cob.

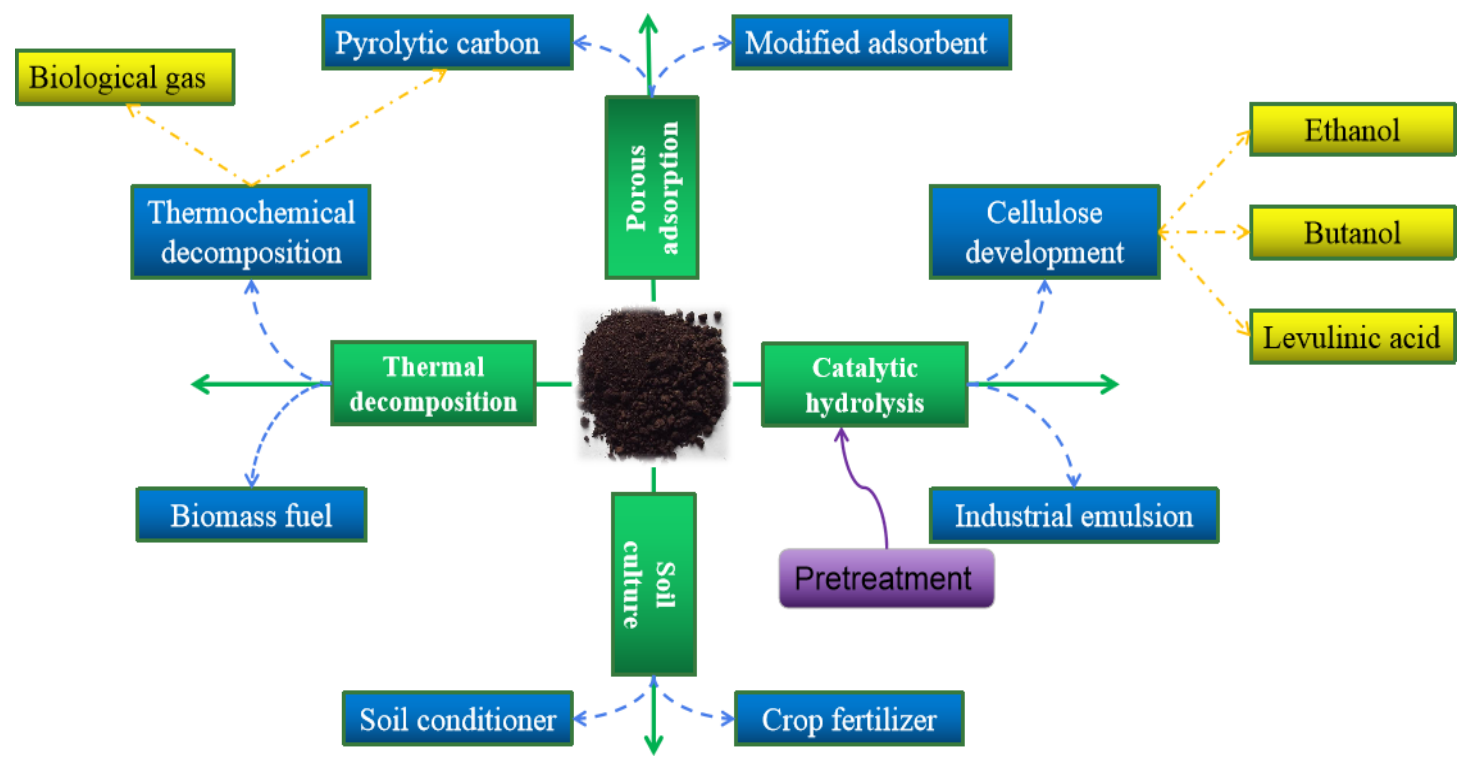

Figure 3. Value-added products of FR in different fields.

(1) Soil culture. Due to the earlier research and more mature technology, FR has been applied to soil culture on a pilot scale. There are two principles to utilize here. One is to neutralize the high alkalinity of saline and desert soils with the strong acidity of FR, or to provide the acidic soil environment for acid-loving plants such as blueberries. The other is to improve the soil structure due to the rich organic matter, and to provide fertilizer for crops.

(2) Catalytic hydrolysis. The proposition of FR hydrolysis and the conversion value-added product comes from the catalytic hydrolysis of lignocellulose. The introduction of the second generation of non-food biofuels makes the hydrolysis of FR into cellulosic ethanol become a hot research topic [7]. Compared with traditional non-food crops (e.g., straw, hay, bagasse, rice husk, wood chips, etc.), the intermolecular forces between the components are weaker in FR, which makes cellulose easier to extract.

(3) Thermal decomposition. FR is used as biomass fuel to generate heat in the early stage of research. With the development of the "bio-refining" concept, biomass pyrolysis as a new technology to optimize the energy structure and reduce greenhouse gas emissions has attracted the attention of government officials. As a potential biomass source, FR has the feasibility to transform biochar due to the fluffy, porous structure and high carbon content [8]. 
(4) Porous adsorption. The adsorption characteristics of FR are mainly related to its specific surface area, porosity degree, and surface chemical properties, which show adsorption capacity on some material such as methyl blue and methyl violet. In addition, further processing can improve the adsorption property of FR, such as thermal decomposition of biochar described above and modification with a chemical activation [9].

\section{Value-Added Products of FR in Soil Culture}

\subsection{Application of FR in Soil Improvement}

As shown in Table 1, FR with a low $\mathrm{pH}$ contains abundant organic matter and a variety of nutrient elements required for plant growth. The content of organic matter and the size specific surface area play an important role in maintaining water and fertilizer and increasing microbial activity, when applied to soil [10]. Therefore, the application of FR as a soil conditioner can significantly improve the quality of the soil, which causes scattered soil particles to form pellets, in order to improve the soil structure, change the $\mathrm{pH}$ of the soil, and increase the content of organic matter in the soil.

Table 1. Nutrient content of FR.

\begin{tabular}{cccccc}
\hline Nutrients & Total Oxygen & $\mathbf{P}_{\mathbf{2}} \mathbf{O}_{\mathbf{5}}$ & $\mathbf{K}_{\mathbf{2}} \mathbf{O}$ & Organic Matter & Minerals \\
\hline Content $(\%)$ & $0.4-0.8$ & $0.3-0.7$ & $2.8-3.4$ & $76-84$ & $14-16$ \\
\hline
\end{tabular}

In China's northeast plain, north China plain, northwest inland, and coastal areas, there are a large number of saline lands [11], which cause perennial soil hardening and fertility decline, form an adverse effect on crop cultivation, and even seriously affect the life and development of people and regions. This brings serious problems to the balanced development of east and west regions of China [12]. Therefore, how to solve the problem of land salinization has always been a concern for people. As a waste product of furfural production, FR can be processed and reused. The organic matter, and the $\mathrm{P}$ and $\mathrm{K}$ element contained in FR, are not consumed during the furfural process. Meanwhile, the acidity of FR can neutralize alkalinity of saline lands. Therefore, FR has a good prospect as a land improver, which can not only increase soil organic carbon content and improve soil structure, but also neutralize soil alkalinity or provide an acidic soil environment [13].

The effects of FR addition on different soils are summarized in Table 2. Part of $\mathrm{Na}^{2+}$ in saline soil can be replaced by $\mathrm{Ca}^{2+}$ in FR, which is excluded from soil along with water flow. This reduces the high sodium content in the soil. Meanwhile, the functional groups of phenolic hydroxyl, carboxyl, methoxy, carbonyl, hydroxyl, and quinone generate a negative charge by dissociating in the humification process of organic matter for FR, which increases the attraction to metal cation and regulates the physical and chemical properties of soil [14]. For example, the absorption of $\mathrm{Ca}^{2+}$ promotes the formation of soil aggregates, and the absorption of $\mathrm{Ni}^{2+}$ and $\mathrm{Pb}^{2+}$ passivates the enrichment rate of heavy metals in the soil. A low $\mathrm{pH}$ value can dissolve and activate some insoluble substances and increase the content of soluble salt in soil, whereas excessive $\mathrm{H}^{+}$promotes the conversion of $\mathrm{N}, \mathrm{P}$, and $\mathrm{K}$ elements, which is conducive to the growth of crops. In addition, the mixture of FR and pulverized coal can synthesize new artificial soil for land reclamation with reasonable fertilizer and water management [15].

However, the costs of transportation and labor limit the real application of FR in soil improvement. Therefore, it is necessary to consider the commercial feasibility and social benefit from the cardinality and transport distance required for FR. 
Table 2. Improvement effect of FR on different soils.

\begin{tabular}{|c|c|c|c|}
\hline Materials & Area & Application Effects & References \\
\hline FR & $\begin{array}{l}\text { Yellow River delta saline } \\
\text { soil }\end{array}$ & $\begin{array}{l}\text { The contents of organic carbon and N, P, and } \mathrm{K} \\
\text { elements increased. The } \mathrm{pH} \text { of soil decreased. }\end{array}$ & [16] \\
\hline FR & $\begin{array}{l}\text { Hexi corridor saline tidal } \\
\text { soil }\end{array}$ & $\begin{array}{c}\text { Soil bulk density and pH decreased. Soil total porosity, } \\
\text { aggregate structure, and water content increased, } \\
\text { organic matter, and N, P, and K element content } \\
\text { increased. }\end{array}$ & [17] \\
\hline $\begin{array}{l}\text { FR } \\
\text { Desulfurization } \\
\text { gypsum }\end{array}$ & Crack solonetz & $\begin{array}{l}\text { Soil structure and permeability were improved, which } \\
\text { promoted the salt leaching rate, reduced alkalinity, and } \\
\qquad \mathrm{pH} \text { value. }\end{array}$ & [18] \\
\hline $\begin{array}{c}\text { FR } \\
\text { Paper dry powder }\end{array}$ & Coastal saline soil & $\begin{array}{l}\text { The } N \text { and } P \text { supply capacity was significantly } \\
\text { improved to alleviate the effects of salinity and alkali } \\
\text { stress on crop growth and nutrient accumulation. }\end{array}$ & [19] \\
\hline FR & $\begin{array}{l}\text { Alkaline soil in Northern } \\
\text { Yinchuan }\end{array}$ & $\begin{array}{l}\text { Soil alkalinity and total salt content decreased. Bulk } \\
\text { density and soil porosity increased. }\end{array}$ & [20] \\
\hline $\begin{array}{c}\mathrm{FR} \\
\text { Coal powder }\end{array}$ & $\begin{array}{l}\text { Coal mine subsidence } \\
\text { area soil }\end{array}$ & $\begin{array}{l}\text { The shortage of backfill soil in the coal mine } \\
\text { subsidence area was solved. The soil after irrigation } \\
\text { and desalination is suitable for agricultural production. }\end{array}$ & [21] \\
\hline FR & Red mud soil & $\begin{array}{l}\text { The } \mathrm{pH} \text { of soil decreased. The stability of } \mathrm{Al}, \mathrm{V} \text {, and } \mathrm{Pb} \\
\text { in red mud was improved by inhibiting the leaching of } \\
\text { metal elements. }\end{array}$ & [22] \\
\hline $\begin{array}{c}\text { FR } \\
\text { Peat/Sawdust }\end{array}$ & Blueberry planting soil & $\begin{array}{l}\text { Improved the physical and chemical properties of soil } \\
\text { and created a slightly acidic environment. }\end{array}$ & [23] \\
\hline $\begin{array}{l}\text { FR } \\
\text { Sulfur }\end{array}$ & Blueberry planting soil & $\begin{array}{l}\text { Increased the content of ammonium and nitrate } \\
\text { nitrogen and provided a slightly acidic environment } \\
\text { for blueberry planting soil. }\end{array}$ & [24] \\
\hline FR & $\begin{array}{l}\text { Aeolian sandy soil in the } \\
\text { irrigation area }\end{array}$ & $\begin{array}{c}\text { Soil aggregates, rapidly available as N, P, K, and Zn } \\
\text { increased. }\end{array}$ & [14] \\
\hline
\end{tabular}

\subsection{Application of FR in Crop Cultivation}

The strong acidity of FR and the high degree of space barrier polymerization of lignocellulose make it difficult to reuse, which result in the waste of nutrients such as cellulose, starch, and organic matter in FR. If these substances are converted into fertilizers that can be absorbed by plants, environmental pollution will be reduced and the reuse of FR will be promoted [25]. At present, the application of FR in crop cultivation is mainly to regulate the growing environment of crops by soil improvement. This can improve crop yield such as blueberry planting and saline planting. The effect of increasing yield on crops with FR fertilizer was listed in Table 3. In addition, some studies showed that artificial substrates made from FR, furnace slag, cow manure, and mushroom residue were feasible for soilless cultivation, and their organic matter content, porosity, moisture content, and rapid available $\mathrm{P}$ and $\mathrm{K}$ indexes were all in line with crop growth indexes [26-28]. It was also reported that FR could replace the cotton seed shell to produce edible fungus rods, which can solve the pollution risk and improve economic benefits [29]. As a substitute for the fertilizer, the FR is applied to crops, which alleviates the contradiction between supply and demand and realizes the value-added process of pollutants. This process achieves a win-win situation. However, the high salinity and acidity of FR will inevitably affect crops, and further research should be carried out to provide solutions. In addition, FR, as a crop additive with a low cost, high adaptability, and strong practicability, has high practical feasibility. However, currently, most reports are focused on potted plant and small-scale experimental fields, and its practical promotion and application still need to be explored. 
Table 3. The effect of increasing yield on crops with FR fertilizer.

\begin{tabular}{cccc}
\hline Cultivated Crops & Planting Soil & Increasing Rate (\%) & References \\
\hline Beet & Saline soil & 16.31 & {$[17]$} \\
Rape & Crack solonetz & 33.09 & {$[18]$} \\
Wheat & Saline soil & 208.54 & {$[30]$} \\
Corn & Saline soil & 118.85 & {$[19]$} \\
Rice & Alkaline soil & 108.62 & {$[20]$} \\
Blueberry & Blueberry planting soil & 55.81 & {$[23]$} \\
Eggplant & Aeolian sandy soil & 3.01 & {$[14]$} \\
Tomato & Soilless cultivation & 35.23 & {$[26]$} \\
\hline
\end{tabular}

\section{Value-Added Products of FR in Catalytic Hydrolysis}

Due to the complex structure of lignocellulosic biomass, it is usually necessary to break the dense structure of lignin, cellulose, and hemicellulose by pretreatment to achieve efficient hydrolysis. As a by-product of lignocellulosic hydrolysis, FR clearly breaks down its original dense structure and reduces the degree of polymerization among the components, which is equivalent to a pretreatment. Large amounts of cellulose and lignin remain. Figure 4 shows the variation of lignocellulose composition in the process of furfural production for corn cob. The content of lignin and cellulose increased significantly (a total of more than $90 \%$ ) and only 3.6\% of hemicellulose is in the form of pentose because of the breakdown of hemicellulose. Cellulose can be hydrolyzed to produce glucose, which is further converted into value-added products such as levulinic acid, ethanol, butanol, and formic acid [31-33]. Lignin can be used as raw material to produce stabilizers, agricultural dispersants, emulsifiers, adhesives, and composite material [34-36]. Therefore, the conversion of FR into value-added products with catalytic hydrolysis has good commercial prospects.

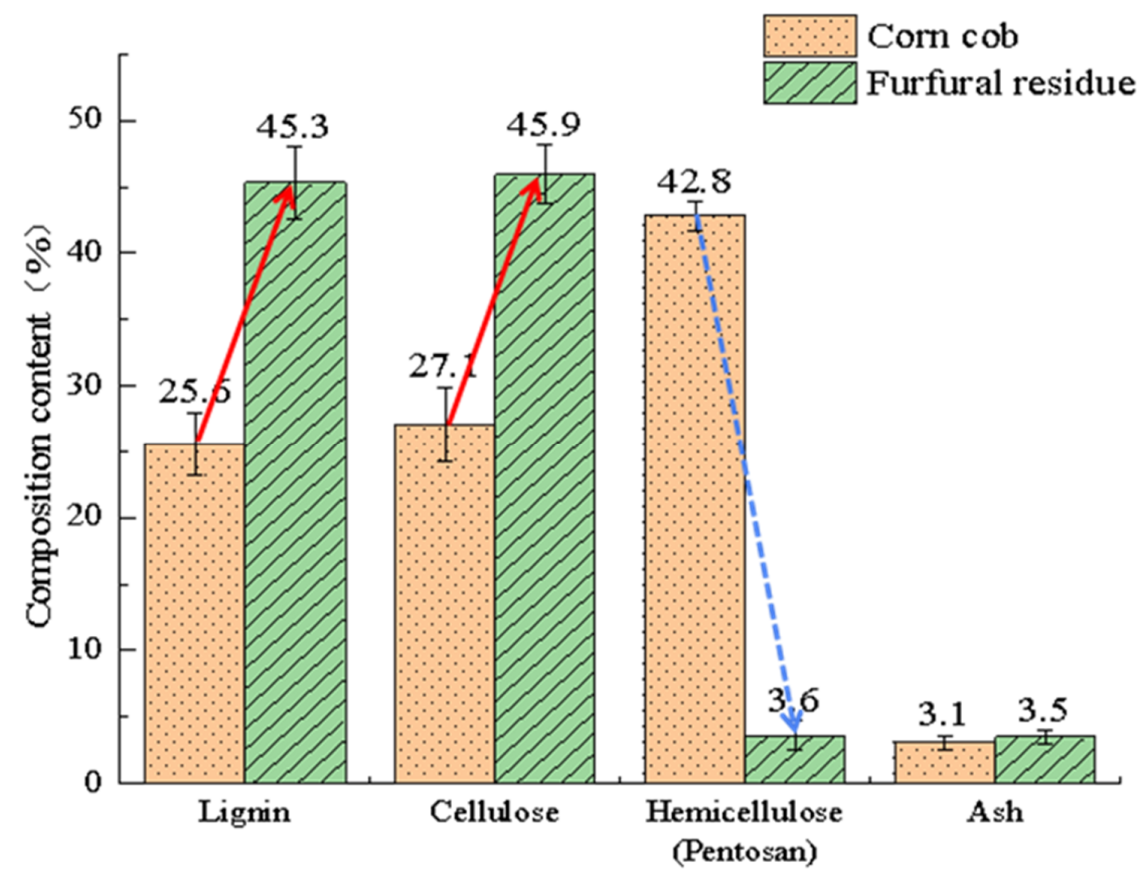

Figure 4. The variation of lignocellulose composition in the process of furfural production for corn on the cob.

\subsection{Extraction and Transformation of Lignin and Cellulose in FR}

The conversion of lignin and cellulose from FR into value-added products is a potential technology. The original cell wall structure of the corn cob is destroyed by the drastic depolymerization in furfural production, which greatly increases the porosity of FR and makes the extraction of lignin and cellulose 
easier. However, lignin is a complex phenolic polymer, which is not easy to be soluted in acidic and neutral solutions, and can only be dissolved in alkaline solutions or organic solvents. This greatly limits the separation of lignin and cellulose [37]. In addition, phenolic hydroxyl groups that can directly affect the physical and chemical properties of lignin and heterogeneous lignin with high protein binding ability are produced by depolymerization and recondensation reactions in furfural production [38]. These substances enable cellulase to be irreversibly adsorbed on lignin, which reduces the efficiency of cellulose extraction and sugar production. Therefore, it is necessary to improve the concentration of cellulose substrates by delignin treatment to reduce the ineffective adsorption of cellulase.

Lignin has a wide range of sources and a low price, whereas the extraction of lignin from FR requires $\mathrm{pH}$ regulation and water washing, which increases the technological complexity. Therefore, there are few studies on the extraction of lignin in FR. Wei [39] proposed that alkaline lignin extracted from FRs could be used to synthesize cheap and recyclable industrial emulsion polymerization materials by utilizing lignin's insoluble characteristics in water but soluble characteristics in alkali. The emulsion developed by this method could wrap polystyrene particles in a neutral environment and a release in the alkaline environment, which can avoid the addition of chemical surfactant or emulsifier in traditional emulsion.

As an intermediate in the synthesis of many chemicals, glucose has high economic value. Therefore, the extraction and conversion of cellulose from FR into value-added products have been the research focus for catalytic hydrolysis of FR [37]. Furthermore, cellulose is hydrolyzed into small molecular compounds such as glucose through appropriate cellulase or acid catalysts, further processing it into different value-added products (Figure 5). For example, industrial ethanol and butanol produced by different fermentation processes [40]. Levulinic acid was prepared under high temperature, high pressure, and catalyst [41]. Therefore, how to optimize and improve the related processes and further improve cellulose hydrolysis and glucose conversion is the focus and difficulty of research.

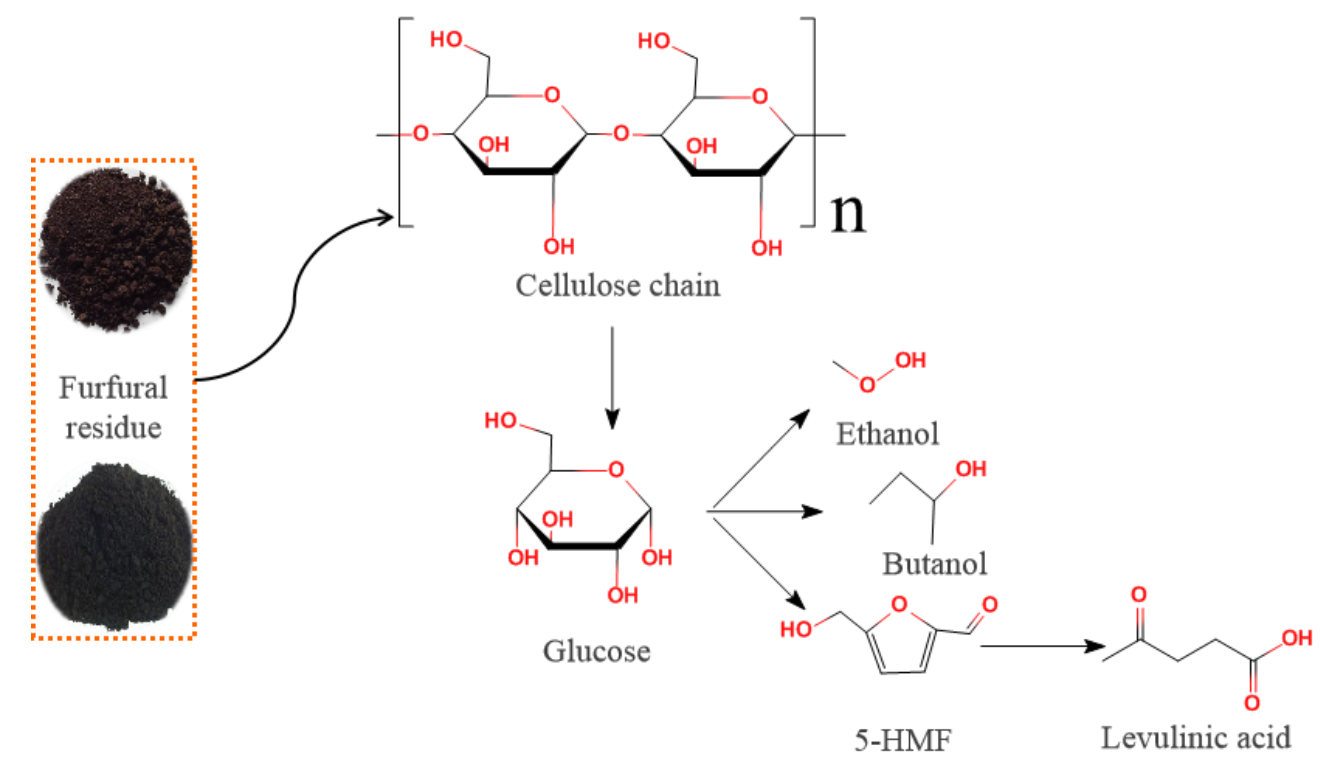

Figure 5. Conversion of cellulose value-added products in FR.

\subsection{The Enhancement of Cellulose Hydrolysis with Different Pretreatment for FR}

Lignin in FR can be reduced by a different pretreatment, which enhances cellulase accessibility and promotes cellulose hydrolysis and glucose conversion. Currently, some pretreatment methods for FR are applied, such as physical (e.g., ultrasonic, microwave, steam explosion, and high temperature), chemical (e.g., acid and alkali), strong oxidant (e.g., hydrogen peroxide and bisulfite), and combined pretreatment. Alkali pretreatment is widely studied due to the simple operation, remarkable effect, and moderate conditions. The $\mathrm{OH}^{-}$in the alkaline substance breaks the ester and $\mathrm{C}-\mathrm{C}$ bonds, which 
removes the amorphous region of the biomass (usually composed of lignin and hemicellulose). This accelerates cellulose hydrolysis [42]. This process has a remarkable effect and mature technology, which was suitable for large-scale industrial production.

To further enhance the pretreatment effect, alkali pretreatment is usually accompanied by other treatments, such as alkaline peroxide, alkaline ethanol, alkaline ultrasound, alkaline microwave, etc. Cooperative physical means of alkali pretreatment can break the unstable hydrogen bond in the amorphous area of lignocellulose through vibration, high temperature, and strong pressure, which is conducive to the degrease of alkali and lignin [43]. This method has short pretreatment time and a clear effect, but harsh conditions and high cost. Alkali pretreatment with a strong oxidant was obtained from the bleaching principle in alkaline pulping, which causes the oxidant to sulfonate with lignin to form the sulfonate group of strong hydrophilicity, and then dissolve lignin sulfonate [44]. This kind of alkali pulping technology was used in the industrial paper and the technical methods have been mature. However, the black liquor produced by alkaline papermaking has been an urgent problem to be solved. In addition, some in-depth studies have further optimized the pretreatment conditions of FR. For instance, the addition of ethylenediamine tetraacetic acid can reduce the ineffective decomposition of hydrogen peroxide in the pretreatment of alkaline hydrogen peroxide in order to improve the pretreatment effect [37]. The released lignin usually needs to be washed away with water in traditional furfural pretreatment to prevent the cellulase from adhering to its surface. The lignin sulfonate produced by sulfonation of bisulfite has a lower affinity for cellulase, which eliminates the washing step and saves cost.

\subsection{Hydrolysis Principle of Cellulose in Acid or Enzyme}

The cellulose hydrolytic product is called hydrolyzed cellulose, which is decomposed into glucose under the action of acids, enzymes, and other factors. The hydrolysis of cellulose with the enzyme is a complex process. At present, the most acceptable enzymatic hydrolysis mechanism is that the cellulose crystallization area is affected by the action of endoglucanase to form a free polysaccharide chain, and the non-reducing end of the polysaccharide chain is further cut into fibrous disaccharide units by cellobiohydrolase. Eventually, glucose is produced via glucoside [45]. The higher substrate sugar yield can be obtained by cellulase hydrolysis, whereas the culture of related hydrolases is more difficult and the input cost is higher. Therefore, the output value after cellulose hydrolysis needs to be evaluated. High-solid enzymes can increase sugar yield and reduce operating costs. The problem is that the mixture produced by FR becomes more viscous in a high solid load, which is not conducive to contact between the enzyme and cellulose. Currently, several additives have been shown to enhance high-solid enzymatic hydrolysis, such as Gleditsia saponin, cocktails, etc. [46,47].

Compared to the former, the hydrolysis of cellulose with acid is slightly less efficient in producing sugar, while its cost-effective input and longer service life give it more potential. Cellulose is generally difficult to dissolve in dilute acid, whereas the free hydroxyl group in cellulose will be esterified with an acid radical to form hydrogen sulfate ester in a concentrated acid medium, such as concentrated sulfuric acid, which breaks the connection between the glucose residues and then dissolves the cellulose. By contrast, catalytic hydrolysis of cellulose by solid carbon-based acid is more environmentally-friendly and recyclable. However, the relevant data [48] showed that the yield of reducing sugar for liquid acid was more than $60 \%$, which only took $2 \mathrm{~h}$, and that for carbon-based solid acid is only $30 \%$. It took $10 \mathrm{~h}$ to achieve the best results. In summary, the efficiency of cellulose hydrolysis can be improved clearly by optimizing the conditions of acid and enzymatic hydrolysis. However, considering all factors, none of the technologies achieved mass production. The main limitation comes from the capital investment of the technology. Table 4 shows the progress in the process of extracting cellulose from the FR and the conversion process in recent years. 
Table 4. The value-added products of cellulose from FR.

\begin{tabular}{|c|c|c|c|c|c|}
\hline Raw Material & Pretreatment & Additives $^{a}$ & Value-Added Products & Effects & References \\
\hline FR & - & Surfactant & Ethanol & Cellulose conversion rate: $78 \%$ & [49] \\
\hline $\begin{array}{c}\text { FR } \\
\text { Corn kernels }\end{array}$ & - & - & Ethanol & Ethanol concentration: $73.1 \mathrm{~g} / \mathrm{L}$ & {$[50]$} \\
\hline FR & - & Lactobacillus/Yeast & $\begin{array}{l}\text { Ethanol } \\
\text { Lactic acid }\end{array}$ & Cellulose conversion rate: $86.8 \%$ & [51] \\
\hline FR & - & Saponin & Ethanol & Ethanol production rate: $22.8 \%$ & [52] \\
\hline FR & Alkaline peroxide & - & Glucose & $\begin{array}{l}\text { Lignin extraction rate: } 12.6 \% \text {, } \\
\text { Saccharification rate: } 86.6 \%\end{array}$ & [53] \\
\hline FR & Formic acid/Peroxide & - & Cellulose & Cellulose production rate: $41.92 \%$ & [54] \\
\hline FR & Alkaline peroxide & Cocktail & Ethanol & $\begin{array}{l}\text { Lignin extraction rate: } 73.5 \% \\
\text { Ethanol concentration: } 16.9 \mathrm{~g} / \mathrm{L}\end{array}$ & [44] \\
\hline FR & Green liquor/Peroxide & - & Glucose & Glucose production rate: $90.4 \%$ & [37] \\
\hline FR & $\begin{array}{l}\text { Green liquor/Ethanol } \\
\mathrm{NaOH} / \text { Peroxide \& }\end{array}$ & - & Glucose & $\begin{array}{l}\text { Glucose production rate: } 85.9 \% \\
\text { Reducing sugar production rate: } 35.7 \%\end{array}$ & [55] \\
\hline FR & $\begin{array}{l}\mathrm{NaOH} / \text { Microwave \& } \\
\mathrm{NaOH} / \text { Ultrasound }\end{array}$ & Carbon-based solid acid & Reducing sugar & $\begin{array}{l}\text { Reducing sugar production rate: } 33.9 \% \\
\text { Reducing sugar production rate: } 33.13 \%\end{array}$ & [43] \\
\hline FR & 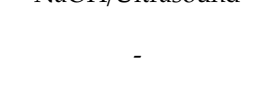 & $\begin{array}{c}\text { Sulfuric acid \& } \\
\text { coal tar acid \& } \\
\text { activated carbon-based acid }\end{array}$ & Reducing sugar & $\begin{array}{l}\text { Reducing sugar production rate: } 66.6 \% \\
\text { Reducing sugar production rate: } 35.7 \% \\
\text { Reducing sugar production rate: } 33.2 \%\end{array}$ & [48] \\
\hline FR & Alkaline peroxide & Ethylene glycol & Liquefied content & Liquefaction rate: $82.0 \%$ & [56] \\
\hline FR & - & Saponin/High solid enzyme & Glucose & Cellulose conversion rate: $74.8 \%$ & [45] \\
\hline FR & Bisulfite & High solid enzyme & Glucose & Glucose production rate: $99.4 \%$ & [5] \\
\hline $\begin{array}{c}\text { FR } \\
\text { Cassava residue }\end{array}$ & - & Saponin & Ethanol & Ethanol concentration: $36.0 \mathrm{~g} / \mathrm{L}$ & [57] \\
\hline FR & Alkaline peroxide & Saponin/High solid enzyme & Ethanol & $\begin{array}{l}\text { Cellulose conversion rate: } 82.2 \% \\
\text { Ethanol concentration: } 69.1 \mathrm{~g} / \mathrm{L}\end{array}$ & [58] \\
\hline FR & Sodium bisulfite & High solid enzyme & Ethanol & Glucose production rate: $99.4 \%$ & [59] \\
\hline $\begin{array}{c}\text { FR } \\
\text { Cassava residue }\end{array}$ & Green liquor/Peroxide & - & Ethanol & $\begin{array}{l}\text { Lignin production rate: } 42.0 \% \\
\text { Ethanol concentration: } 51.9 \mathrm{~g} / \mathrm{L}\end{array}$ & [60] \\
\hline FR & Alkaline peroxide & - & Ethanol & Cellulose conversion rate: $88.6 \%$ & [61] \\
\hline FR & $\begin{array}{l}\text { Alkaline sodium } \\
\text { hypochlorite }\end{array}$ & Activated carbon/Resin & Butanol & Butanol concentration: $8.48 \mathrm{~g} / \mathrm{L}$ & {$[62]$} \\
\hline
\end{tabular}

Note: ${ }^{a}$ Where there is no emphasis on acids or enzymes, the default is traditional acids or enzymes, which are not listed. \& indicates different methods. 


\section{Value-Added Products of FR in Thermal Decomposition}

Thermal decomposition is a new method for the reuse of FR, including the thermogravimetric change, final temperature, and heating rate on product properties and distribution, which broadens the practical application field of FR $[63,64]$. Currently, the research on the pyrolysis of FR is in the stage of development from theoretical research to the combination of theory and practical application at present.

\subsection{Application of FR in Thermal Decomposition}

Thermal decomposition is one of the methods of biomass energy utilization, including direct combustion and thermochemical technology. Direct combustion is the most common means of biomass utilization, which burns biomass raw materials directly in contact with air or processes them into specific fuels for use in combustion equipment [65]. Because of the convenience of operation, this technique is an early way to treat FR. However, FR has low calorific value, high moisture content, and high sulfur content, which is not easy to direct combustion. It is necessary to carry out certain pretreatment before heating the boiler or generating electricity for the power plant. For example, the circulating fluidized bed combustion technology has characteristics of stable combustion, strong applicability, and sulfur fixation in the furnace, which can make the FR continuously stable combustion [66]. In addition, multi-fuel co-combustion has been a major topic in direct combustion research because it can improve the combustion performance. As a kind of biomass raw material, FR has also been studied in the co-combustion. The addition of FR can improve combustion efficiency and reduce sulfur gas emission in coal biomass briquette. This is because the FR burned before coal biomass briquette forms a relatively loose gap, which is conducive to the combination of sulfur and the sulfur fixation agent as well as the contact combustion of oxygen and materials [67]. In the co-combustion of furfural residue and oil shale semi-coke, it was found that the effect between them is not simply the superposition of calorific value, but the co-promotion of combustion characteristics through some synergistic action [68].

The thermochemical application of FR mainly includes pyrolysis technology and biomass gasification technology. The former refers to the process of converting raw materials into solid, liquid, and gas three-phase low molecular substances by thermochemical conversion under low oxygen or anaerobic conditions [65]. Biochar or adsorbents from thermal cracking of furfural residue show good porosity and a high specific area (specific area: $567 \mathrm{~m}^{2} / \mathrm{g}$, vtotal: $0.38 \mathrm{~cm}^{3} / \mathrm{g}$ ), which completely meets the basic requirements of activated charcoal, especially clear adsorption effects on various metal ions, methyl blue, and tetracycline [69]. In addition, nuclear magnetic resonance technology can track and scan the whole process of preparing activated carbon from FR, determine the changes of carbon structure, electron transfer, surface chemistry, and adsorption capacity in the process, and provide a theoretical basis for further research on the preparation of economical, practical, diversified, and specialized biomass activated carbon from the pyrolysis of FR [70]. The latter refers to the process of using a small amount of oxygen or oxygen-containing substances as a gasification agent under incomplete combustion conditions to convert the combustible components in raw materials into carbon dioxide, hydrogen, methane, and other combustible gases by means of a high-temperature overheating chemical method. For example, furfural residue and waste fungus sticks were gasified in the absence of oxygen to prepare biomass combustible gas [71].

\subsection{Mechanism Analysis of Thermal Decomposition for FR}

Thermal decomposition of FR is a complex intermolecular process, it is necessary to analyze the morphological transformation of various substances and functional groups in the thermal decomposition and gasification, which can provide a theoretical basis for the design of efficient pyrolysis devices and in-depth exploration of the pyrolysis characteristics for FR.

Generally, there are four kinds of chemical bonds in lignocellulosic materials [72]. 
The first type includes the aliphatic series/ aromatic carbon groups in lignin $(\mathrm{C}-\mathrm{C} / \mathrm{C}-\mathrm{H})$.

The second type includes the hydroxyl in cellulose and hemicellulose $(-\mathrm{OH})$.

The third type includes the carbonyl or single carbonyl carbon in lignin and hemicellulose $(C=O)$.

The fourth type includes the ester bond in the hemicellulose carboxyl group $(\mathrm{O}-\mathrm{C}=\mathrm{C})$.

Most hemicellulose is hydrolyzed for furfural production, which indicates that the change of the remaining hydroxyl group determines the state of cellulose. The structural units of cellulose and lignin in FR are shown in Figure 6a,b. With the increase of temperature, the phenomenon was found by Thermogravimetric Analyzer-Fourier Transform Infrared Spectroscopy (TG-FTIR) that the water in FR first evaporates, which is followed by dehydration and dehydroxylation, and more gaseous products were released with the further increase of temperature. Therefore, the components of FR were separated in the following order: water, a small amount of hemicellulose, cellulose, and lignin [73]. In terms of the generated gas composition, carboxyl can be formed into $\mathrm{CO}_{2}, \mathrm{CO}$, or $\mathrm{H}_{2} \mathrm{O}$. Among them, $-\mathrm{OH}$ is cleaved into $\mathrm{H}_{2} \mathrm{O}$, while the lateral $\mathrm{C}=\mathrm{O}$ bond fracture generates $\mathrm{CO}_{2}$ or $\mathrm{CO}$ and methoxy and methylene produce $\mathrm{CH}_{4}$. Therefore, the gas products of thermal decomposition are mainly $\mathrm{CO}_{2}$, $\mathrm{H}_{2} \mathrm{O}, \mathrm{CO}$, and $\mathrm{CH}_{4}$ [74].

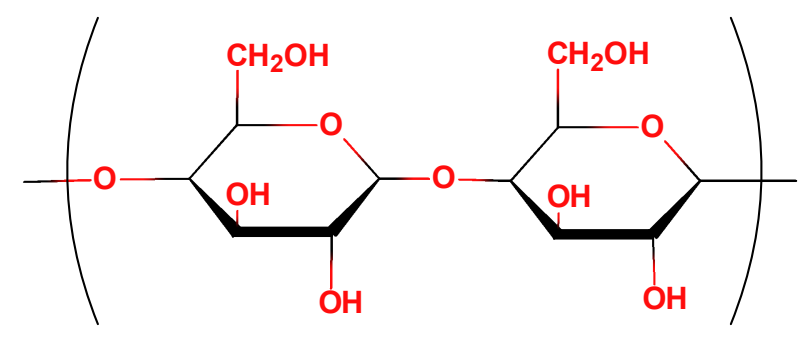

(a)

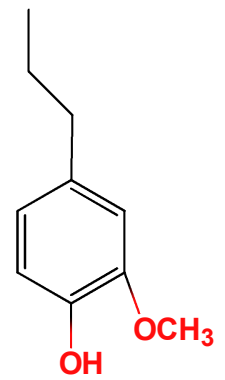

Guaiacyl lignin<smiles>CCCc1cc(OC)c(O)c(OC)c1</smiles>

Syringyl lignin Para-hydroxy-phenyl lignin

(b)

Figure 6. The main composition structure of lignocellulose in FR. (a) Structural unit of cellulose and (b) structural unit of lignin.

In addition, many parallel and serial complex reactions often occur during biomass pyrolysis due to the diversified structure of components, it is necessary to analyze the process by thermogravimetry and simulate the relevant kinetic parameters. In the current biomass pyrolysis kinetic model, the coasts method, dolye method, and the maximum rate atia method are most commonly used [75]. For different pyrolysis types, the models are selected and applied differently, while, for non-isothermal degradation materials such as FR, Coats-Redfern integration is usually applied [76]. Therefore, kinetic models of non-isothermal degradation materials are often selected to establish dynamic models of FR $[74,77]$. The kinetic model is shown below.

$$
f(a)=\frac{A R T^{2}}{E} e^{-E / R T}
$$


Additionally, the model is also applicable to the analysis of the co-pyrolysis characteristics of FR and other substances [78].

\section{Value-Added Products of FR in Porous Adsorption}

Adsorption is a mass transfer process, which is manifested in the adsorption of solid adsorbent to non-electrolyte molecules. For materials with a larger specific surface area, although the internal molecules attract each other, the external molecular forces are not fully exerted. Therefore, some relatively large areas of materials such as water film, activated carbon, and more are often used as adsorption materials in industry [79]. The specific surface area is not the only parameter that determines the adsorption characteristics, but is also related to the chemical properties of surface functional groups.

\subsection{Evaluation of Adsorption Capacity of FR}

In the production of furfural, most of the hemicellulose in the raw material is removed by hydrolysis, and the obtained FR is mainly composed of structurally altered cellulose, lignin, and a small amount of hemicellulose. From the scanning electron microscope in Figure 7, there are a few gaps and protrusions on the surface of the corn cob, but the overall structure is dense with few channels or porous structures, which presents a smooth layered structure (Figure 7a,b). In contrast, FR has a rougher surface with more particles and a pore size (Figure 7c,d). The surface of the cob becomes wrinkled in furfural production due to the violent depolymerization reaction, which greatly increases the specific surface area.
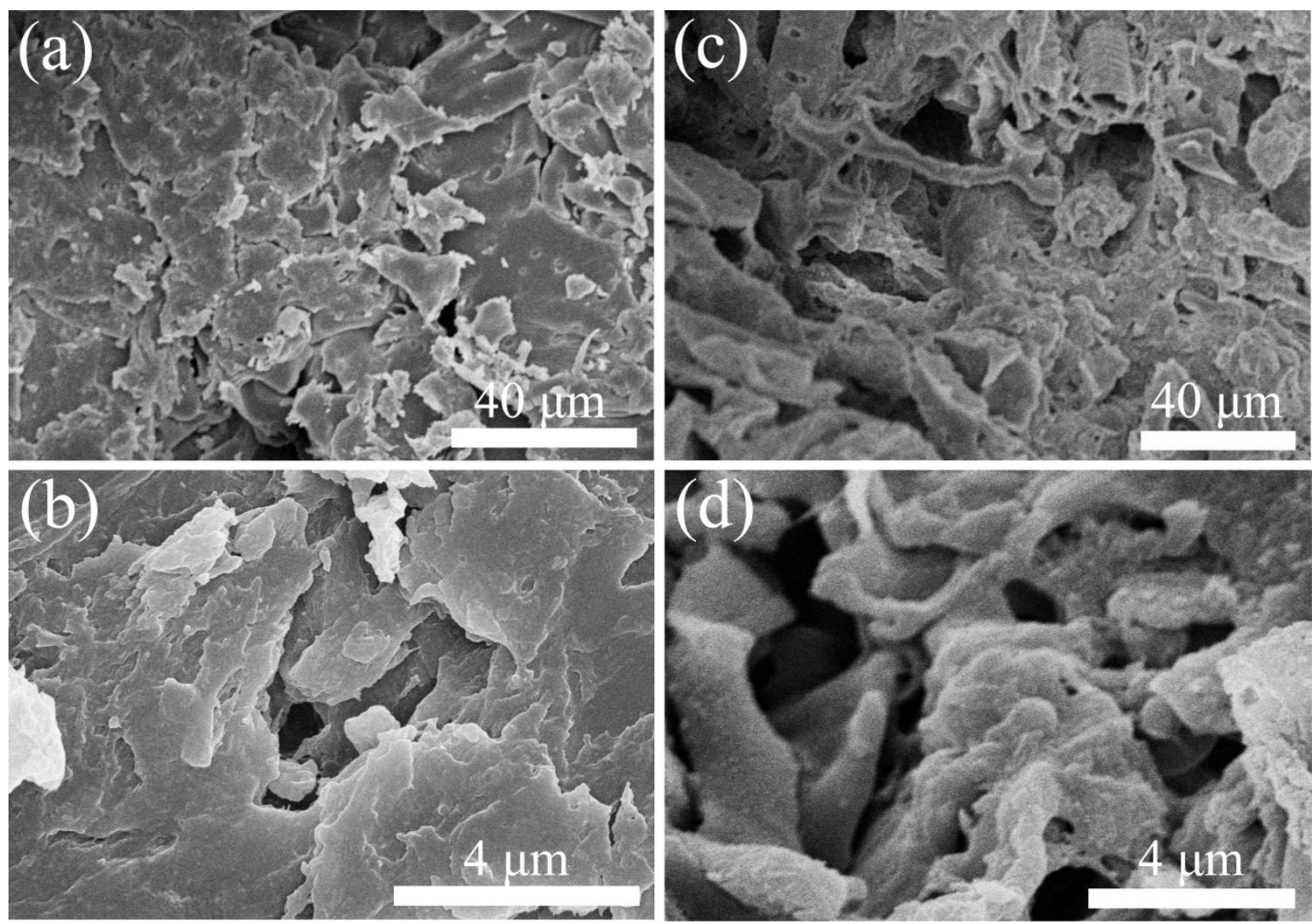

Figure 7. Scanning electron micrographs of $\operatorname{corn} \operatorname{cob}(\mathbf{a}, \mathbf{b})$ and FR $(\mathbf{c}, \mathbf{d})$.

On the other hand, there are many nonpolar bonds in the FR, whereas the polar bonds such as carboxyl and hydroxyl are relatively few. According to the principle of similarity and intermiscibility, the adsorbent prepared from FR has weak adsorption on polar molecules such as water, but stronger 
adsorption on a nonpolar substance in aqueous solution, which provides a possibility for the adsorption of nonpolar substances in a strong, polar aqueous solution. Furthermore, it is necessary to further activate before preparation of the mature adsorbent product to enhance the adsorption capacity. Currently, the activation of FR are mainly the physical activation method and the chemical activation method. The former has less pollution and lower cost, but the process conditions are harsh, which requires high temperature and low oxygen. The latter is mild and can control the aperture structure and performance by adjusting the activation conditions, but the corrosion resistance of the equipment is high and it is easy to produce pollutants.

\subsection{Preparation of Biomass Adsorbent Product from $F R$}

In the development of the early adsorption application for FR, the residue body is simply washed, crushed, and mixed with the adsorbed liquid, and the adsorption effect was evaluated by measuring the residual concentration of the adsorbed substance [80-82]. With the development of technology, FR is often used to prepare highly active biomass adsorbent via further activation by physical and chemical methods.

The physical activation method, which is the pyrolysis technology mentioned in Section 3.1, obtains biomass adsorption carbon with larger aperture and higher mechanical strength by pyrolysis and a polycondensation reaction of organic components in FR. However, the newly formed products in the carbonization process of furfural residue tend to accumulate in the pore diameter, which reduces the adsorption performance of biomass charcoal. Some strategies can reduce this negative effect. For example, the oxidation gas introduced into the thermal carbonization process can effectively remove the residual material and carry out selective oxidation on the highly reactive sites in the FR, which further expands the pore diameter of the carbon structure [83,84]. Microwave and other auxiliary means can also accelerate the internal thermal activation process of activated carbon, which effectively expands the carbonization aperture [85,86]. In addition, Yin et al. [69] proposed a self-activation method of biochar activated by pyrolysis gas of FR. Essentially, the pyrolytic gas generated from the pyrolysis of FR is directly injected into the carbonization reactor to promote the activation of biomass charcoal, so as to produce low cost but high performance biochar.

The chemical activation method refers to the modified biomass carbon adsorbent obtained by mixing furfural residue with a related activator, which is treated by heating, washing, and drying. There are many activators commonly used to modify FR such as zinc chloride [87], basic epichlorohydrin [88], basic isopropanol/citric acid [89], sodium phenolate [90], sodium carbonate [91], and sulfuric acid [4]. The principle is that the functional groups of activated carbon and their own acid and alkali are changed by impregnation, alkali, acid, salt, and other treatment means, so as to mention the adsorption capacity of activated carbon. In addition, the addition of the activator in the carbonization process can release hydrogen and oxygen from FR in the form of water, and inhibit the decomposition of high polymer and the formation of tar [92], which is conducive to the carbonization heating process. This reduces the carbonization temperature and saves energy consumption.

Adsorption capacity is critical for adsorbents. Maximum adsorption per unit is an authoritative measure of adsorption capacity. The preparation methods and maximum adsorption per unit of different types of FR adsorbents were listed in Table 5. The comprehensive analysis of the results shows that the furfural residue has a certain adsorption effect as a biomass adsorption material. It is feasible to prepare high-performance activated carbon by further exploration and development.

High-performance activated carbon has been the most popular and widely used adsorbent, whereas the problem of high prices has not been solved. As a substitute of the adsorbent, cheap FR has good potential research value, which provides the feasibility and reference basis for making the adsorbent from FR. 
Table 5. Adsorption effect of FR adsorbent on different substances.

\begin{tabular}{cccc}
\hline Adsorbed Material & Adsorption Capacity $(\mathbf{m g} / \mathbf{g})$ & Activation Method & Reference \\
\hline Methylene blue $\mathrm{Cr}^{6+}$ & 202.5 & $\mathrm{ZnCl} /$ Microwave & {$[87]$} \\
Methylene blue & 7.583 & - & {$[80]$} \\
$\mathrm{Ni}^{2+}$ & 47.7 & $\mathrm{NaOH} /$ Isopropanol/Citric acid & {$[89]$} \\
$\mathrm{Pb}^{2+}$ & 19.0 & - & {$[81]$} \\
$\mathrm{Cr}^{6+}$ & 46.4 & $\mathrm{NaOH} /$ Epichlorohydrin & {$[9]$} \\
$\mathrm{Cd}^{2+}$ & 93.9 & & \\
$\mathrm{Ni}^{2+}$ & 18.3 & $\mathrm{NaOH} /$ Phenol/Formaldehyde & {$[90]$} \\
$\mathrm{Pb}^{2+}$ & 98.2 & & \\
$\mathrm{Cu}^{2+}$ & 34.8 & & \\
$\mathrm{Zn}^{2+}$ & 45.1 & $\mathrm{Concentrated} \mathrm{sulfuric} \mathrm{acid}$ & {$[4]$} \\
Tetracycline & 14.7 & & \\
Terramycin & 162.0 & $\mathrm{CaO} / \mathrm{KCO}_{3} /$ Microwave & {$[86]$} \\
Iodine & 335.0 & & \\
Methylene blue & 127 & 59 &
\end{tabular}

Note: Heat treatment is not indicated.

\section{Conclusions and Future Perspectives}

As a by-product of furfural production, FR has been well studied in soil culture, catalytic hydrolysis, thermal decomposition, and porous adsorption due to its composition and structural characteristics. There are many value-added products from FR that have been converted. However, the treatment and reuse of FR remains a challenge and there are two critical reasons for furfural residue to convert value-added products. One reason is that the production of FR only increased but did not decrease due to the limitation of production technology and high intensity operation for furfural enterprises. Another is that the use of FR as raw materials is not an economically viable selectivity and the willingness for furfural enterprise is still low. Hence, the scale operation is the most fatal problem for FR treatment technology. For value-added products in the above research domains, only biomass fuel, soil conditioner, and crop fertilizer can be produced on a large scale, but there are also corresponding problems.

At present, biomass fuel products are the main utilization of furfural residue, but the essence is only the transformation of the pollution source from solid waste to a gas source, which is far from the concept of "green" and "friendly." Soil conditioner products are severely restricted by objective factors, such as the particularity of the soil to be treated (alkaline soil) and the harsh transportation conditions (transportation distance and transportation location). The crop fertilizer from RF is only suitable for acidophilous soil, which narrows the application range.

Cellulosic ethanol production is the most promising scheme from a range of value-added products for FR conversion. As a high-end clean energy technology, cellulosic ethanol technology is highly expected. Despite this, some obstacles must be overcome, especially the cost. Therefore, it is likely to be a while before cellulosic ethanol can be considered seriously for industrial-scale production. Fortunately, with the improvement of cellulosic ethanol technology, it will become more economical to obtain ethanol from furfural residues. To sum up, there are a variety of value-added products for furfural residue conversion. However, there is a need to rapidly develop new technologies that can break through economic bottlenecks or find other potential applications in future exploration. In addition, it is also of practical significance to improve the production system of furfural from the source, such as to reduce FR production and regulate acidity by improving the production efficiency of furfural and using recyclable catalysts.

Author Contributions: Y.S. is the corresponding author of the manuscript. Y.S. and Z.W. contributed to analysis and manuscript preparation. Z.W. performed the data analysis and wrote the manuscript. B.Q. and C.L. helped guide many professional problems of English paper writing. J.Q., X.M., and Y.L. revised the manuscript. All authors have read and agreed to the published version of the manuscript.

Funding: This research received no external funding. 
Acknowledgments: The authors are grateful for the support of National Key R\&D Program of China (2019YFD1100603), the Development of Local Science and Technology grant number (ZY17C05), and the Harbin special fund for scientific and technological innovation talents research project (2016RAXXJ009).

Conflicts of Interest: The authors declare no conflict of interest.

\section{References}

1. Liu, L.; Chang, H.-M.; Jameel, H.; Park, S. Furfural production from biomass pretreatment hydrolysate using vapor-releasing reactor system. Bioresour. Technol. 2018, 252, 165-171. [CrossRef] [PubMed]

2. Deng, A.; Lin, Q.; Yan, Y.; Li, H.; Ren, J.; Liu, C.; Sun, R. A feasible process for furfural production from the pre-hydrolysis liquor of corncob via biochar catalysts in a new biphasic system. Bioresour. Technol. 2016, 216, 754-760. [CrossRef] [PubMed]

3. Mao, L.; Zhang, L.; Gao, N.; Li, A. FeCl3 and acetic acid co-catalyzed hydrolysis of corncob for improving furfural production and lignin removal from residue. Bioresour. Technol. 2012, 123, 324-331. [CrossRef] [PubMed]

4. Bi, S.; Liu, W.; Wang, C.; Zhan, H. A versatile approach to the synthesis of biomass derived from furfural residues as a potential adsorbent. J. Environ. Chem. Eng. 2018, 6, 5049-5052. [CrossRef]

5. Xing, Y.; Bu, L.; Sun, D.; Liu, Z.; Liu, S.; Jiang, J. High glucose recovery from direct enzymatic hydrolysis of bisulfite-pretreatment on non-detoxified furfural residues. Bioresour. Technol. 2015, 193, 401-407. [CrossRef]

6. Yin, Y.; Li, A.; Mao, L. Progress in utilization of furfural residue utilization technology. Mod. Chem. Ind. 2011, 31, 22-26.

7. Smit, A.T.; Huijgen, W.J.J. The promotional effect of water-soluble extractives on the enzymatic cellulose hydrolysis of pretreated wheat straw. Bioresour. Technol. 2017, 243, 994-999. [CrossRef]

8. Jiang, W.; Xing, X.; Li, S.; Zhang, X.; Wang, W. Synthesis, characterization and machine learning based performance prediction of straw activated carbon. J. Clean. Prod. 2019, 212, 1210-1223. [CrossRef]

9. Zhang, R.L.; Zhu, C.S.; Wang, Q.J.; Wang, T. Adsorption properties of Cr(VI) from wastewater by modified furfural residue. Chem. Eng. 2015, 29, 26-29.

10. Lin, H.; Chapman, S.J.; Freitag, T.E.; Kyle, C.; Ma, J.; Yang, Y.; Zhang, Z. Fate of tetracycline and sulfonamide resistance genes in a grassland soil amended with different organic fertilizers. Ecotoxicol. Environ. Saf. 2019, 170, 39-46. [CrossRef]

11. Tao, Y.; Wu, G.L.; Zhang, Y.M. Dune-scale distribution pattern of herbaceous plants and their relationship with environmental factors in a saline-alkali desert in Central Asia. Sci. Total Environ. 2017, 576, 473-480. [CrossRef] [PubMed]

12. Long, X.H.; Liu, L.P.; Shao, T.Y.; Shao, H.B.; Liu, Z.P. Developing and sustainably utilize the coastal mudflat areas in China. Sci. Total Environ. 2016, 569, 1077-1086. [CrossRef] [PubMed]

13. Dou, Y.N.; Zhang, Y.P.; Cui, G. Study on Preparation of Humic Acid Soluble Fertilizer by Using Furfural Residue. J. Anhui Agric. Sci. 2015, 43, 41-43.

14. Li, S.F.; Qin, C.; Yan, G.; Sang, Z.; Chen, X.B. Effects of Ecological Fertilizer from Furfural Residue on Physical and Chemical Properties of Sand Soil and Eggplant Benefits. Soils 2016, 48, 893-900.

15. Zhang, L.N.; Feng, Y.J.; Wang, Z.F. A kind of mixed media composed of fly ash and acid residue of furfural for land reclamation and its leaching requirement. Trans. Chin. Soc. Agric. Eng. 2004, 20, 268-272.

16. Sun, J.N.; Dong, L.K.; Xu, G.; Shao, H.B. Effects of Furfural and Its Biochar Additions on Physical-chemical Characteristics of a Saline Soil. J. Agro-Environ. Sci. 2014, 33, 532-538.

17. Qin, J.H.; Jin, Z.X.; Chen, X.B.; Hou, D.M.; Liu, Y.H.; Chen, G.Q.; Yang, D.J. Effect of Potassium Containing Organic Offal Furfural Dreg on Soil Fertility. Chin. J. Soil Sci. 2007, 38, 705-708.

18. Yang, J.; Sun, Z.J.; Liu, J.L.; Ma, F. Effects of saline improvement and leaching of desulphurized gypsum combined with furfural residue in newly reclaimed farmland crack alkaline soil. Trans. Chin. Soc. Agric. Eng. 2015, 31, 128-135.

19. Cui, X.; Hu, J.; Lin, X.; Yang, J. Effects of Application of Dry Paper-Making Waste Powder and Furfural Residue on Maize Growth and Microbiological Properties of Coastal Saline-Alkaline Soil. J. Ecol. Rural Environ. 2014, 30, 331-335.

20. Luo, C.K.; Lv, W.; Xu, X.; Sun, Z.J.; Shen, Z.R. Effect of furfural residue on improving alkalized soil in north yinchuan. Jiangsu Agric. Sci. 2008, 2008, 232-234. 
21. Feng, Y.J.; Fen, L.I.; Wang, X.L.; Liu, X.M.; Zhang, L.N. Principal chemical properties of artificial soil composed of fly ash and furfural residue. Pedosphere 2006, 16, 668-672. [CrossRef]

22. Ren, J.; Liu, J.D.; Chen, J.; Liu, X.L.; Li, F.S. Effects of Vinegar and Furfural Residue on Metal Stability in Bauxite Residue. Res. Environ. Sci. 2016, 29, 1895-1903.

23. Ji, Q.Y.; Liu, X.J.; Liu, A.B.; Zhou, X.M.; Liu, B.; Che, W.L. Replacement of Sulphur with Furfural Residue to Regulate Soil pH and Its Effects on Growth and Development of Blueberry. South China Fruits 2013, 42, 15-17.

24. Wang, R.Q.; Jing, D.W. Application Research on Furfural Residue in Improving Soil Physical and Chemical Properties of Blueberry. Shandong Agric. Sci. 2017, 49, 98-102.

25. Osborne, W.E.R.; Osborne, S.L. Row and forage crop rotation effects on maize mineral nutrition and yield. Can. J. Plant Sci. 2017, 97, 645-653, CJPS-2017-0006.

26. Qin, J.H.; Chen, G.Q.; Chen, X.B. The effect of N.P.K mixed application on yields and quality of tomato in solar greenhouse. China Veg. 1997, 4, 10-13.

27. Xu, Z.Y.; Zhang, G.Y.; Shen, J.H. The Research on Application of the Mixed Media of Furfural Residue in Artificial Culture of Soilless Grass Blanket. J. Anhui Agric. Sci. 2009, 37, 11962-11963.

28. Zhang, Y. Application of organic matrix in soilless culture of tomato. Agric. Jilin 2011, 2, 130-131.

29. Xu, X.Y.; Li, D.S.; Zhang, Y. Study on furfural residue cultivation of oyster mushroom. Environ. Pollut. Control 1996, 37-38. [CrossRef]

30. Cui, X.; Hu, J.; Lin, X.; Yang, J.; Xu, J.; Wang, Y.; Wang, J. Effects of Dry Powered Sludge and Furfural Residue on Wheat Growth on Saline-alkaline Fields. Environ. Sci. Technol. 2014, 37, 25-29.

31. Tye, Y.Y.; Lee, K.T.; Wan Abdullah, W.N.; Leh, C.P. The world availability of non-wood lignocellulosic biomass for the production of cellulosic ethanol and potential pretreatments for the enhancement of enzymatic saccharification. Renew. Sustain. Energy Rev. 2016, 60, 155-172. [CrossRef]

32. Ko, J.K.; Lee, S.-M. Advances in cellulosic conversion to fuels: Engineering yeasts for cellulosic bioethanol and biodiesel production. Curr. Opin. Biotechnol. 2018, 50, 72-80. [CrossRef] [PubMed]

33. Xin, F.; Dong, W.; Zhang, W.; Ma, J.; Jiang, M. Biobutanol Production from Crystalline Cellulose through Consolidated Bioprocessing. Trends Biotechnol. 2019, 37, 167-180. [CrossRef] [PubMed]

34. Fierro, C.M.; Górka, J.; Zazo, J.A.; Rodriguez, J.J.; Ludwinowicz, J.; Jaroniec, M. Colloidal templating synthesis and adsorption characteristics of microporous-mesoporous carbons from Kraft lignin. Carbon 2013, 62, 233-239. [CrossRef]

35. Yang, D.; Qiu, X.; Zhou, M.; Lou, H. Properties of sodium lignosulfonate as dispersant of coal water slurry. Energy Convers. Manag. 2007, 48, 2433-2438. [CrossRef]

36. Stewart, D. Lignin as a base material for materials applications: Chemistry, application and economics. Ind. Crops Prod. 2008, 27, 202-207. [CrossRef]

37. Yu, H.-L.; Tang, Y.; Xing, Y.; Zhu, L.-W.; Jiang, J.-X. Improvement of the enzymatic hydrolysis of furfural residues by pretreatment with combined green liquor and hydrogen peroxide. Bioresour. Technol. 2013, 147, 29-36. [CrossRef]

38. Wang, K.; Yang, H.; Yao, X.; Xu, F.; Sun, R.-C. Structural transformation of hemicelluloses and lignin from triploid poplar during acid-pretreatment based biorefinery process. Bioresour. Technol. 2012, 116, 99-106. [CrossRef]

39. Wei, Z.; Yang, Y.; Yang, R.; Wang, C. Alkaline lignin extracted from furfural residues for pH-responsive Pickering emulsions and their recyclable polymerization. Green Chem. 2012, 14, 3230. [CrossRef]

40. Bansal, A.; Illukpitiya, P.; Tegegne, F.; Singh, S.P. Energy efficiency of ethanol production from cellulosic feedstock. Renew. Sustain. Energy Rev. 2016, 58, 141-146. [CrossRef]

41. Claudia, A.; Enrico, B.; Domenico, L.; Nicoletta, N.O.D.N.; Anna Maria, R.G. Hydrothermal Conversion of Giant Reed to Furfural and Levulinic Acid: Optimization of the Process under Microwave Irradiation and Investigation of Distinctive Agronomic Parameters. Molecules 2015, 20, 21232-21253.

42. Kim, J.S.; Lee, Y.Y.; Kim, T.H. A review on alkaline pretreatment technology for bioconversion of lignocellulosic biomass. Bioresour. Technol. 2016, 199, 42-48. [CrossRef] [PubMed]

43. Ma, B.J.; Sun, Y.; Lin, K.Y.; Li, B.; Liu, W.Y. Physicochemical pretreatments and hydrolysis of furfural residues via carbon-based sulfonated solid acid. Bioresour. Technol. 2014, 156, 189-194. [CrossRef] [PubMed]

44. Wang, K.; Yang, H.; Chen, Q.; Sun, R.-C. Influence of delignification efficiency with alkaline peroxide on the digestibility of furfural residues for bioethanol production. Bioresour. Technol. 2013, 146, 208-214. [CrossRef] [PubMed] 
45. Xing, Y.; Ji, L.; Liu, Z.-P.; Zhang, W.-M.; Jiang, J.-X. Effects of Gleditsia saponin on high-solids enzymatic hydrolysis of furfural residues. Ind. Crops Prod. 2015, 64, 209-214. [CrossRef]

46. Caspeta, L.; Caro-Bermúdez, M.A.; Ponce-Noyola, T.; Martinez, A. Enzymatic hydrolysis at high-solids loadings for the conversion of agave bagasse to fuel ethanol. Appl. Energy 2014, 113, 277-286. [CrossRef]

47. Zhang, M.; Ouyang, J.; Liu, B.; Yu, H.; Jiang, T.; Cai, C.; Li, X. Comparison of Hydrolysis Efficiency and Enzyme Adsorption of Three Different Cellulosic Materials in the Presence of Poly(ethylene Glycol). Bioenergy Res. 2013, 6, 1252-1259. [CrossRef]

48. Lin, K.; Ma, B.; Sun, Y.; Liu, W. Comparison between liquid and solid acids catalysts on reducing sugars conversion from furfural residues via pretreatments. Bioresour. Technol. 2014, 167, 133-136. [CrossRef]

49. Zhang, L.; Li, T.; Wang, L.; Li, S.Z. Enzymatic hydrolysis of corncob residues of furfural manufacture and optimum conditions for cellulos conversion. Trans. Chin. Soc. Agric. Eng. 2009, 25, 226-230.

50. Tang, Y.; Zhao, D.; Cristhian, C.; Jiang, J. Simultaneous saccharification and cofermentation of lignocellulosic residues from commercial furfural production and corn kernels using different nutrient media. Biotechnol. Biofuels 2011, 4, 22. [CrossRef]

51. Tang, Y.; Zhao, D.; Zhu, L.; Jiang, J. Simultaneous saccharification and fermentation of furfural residues by mixed cultures of lactic acid bacteria and yeast to produce lactic acid and ethanol. Eur. Food Res. Technol. 2011, 233, 489. [CrossRef]

52. Tang, Y.; Su, Z.Q.; Zhao, D.Q.; Qi, X.; Jiang, J.X. The Effect of Gleditsia Saponin on Simultaneous Saccharification and Fermentation of Furfural Residue for Ethanol Production. Adv. Mater. Res. 2011, 236, 108-111. [CrossRef]

53. Gao, Y.X.; Pu, L.X.; Xing, Y.; Jiang, J.X. Furfural Residues Properties and Enzymatic Hydrolysis after Alkali Pretreatment. Biomass Chem. Eng. 2011, 45, 24-30.

54. Yuan, Y.; Zhu, C.; Zhang, X. Extraction of cellulose from furfural residue. Chem. Ind. Eng. Prog. 2013, 32, 466-469.

55. Yu, H.; Xing, Y.; Lei, F.; Liu, Z.; Liu, Z.; Jiang, J. Improvement of the enzymatic hydrolysis of furfural residues by pretreatment with combined green liquor and ethanol organosolv. Bioresour. Technol. 2014, 167, 46-52. [CrossRef] [PubMed]

56. Wu, S.; Ji, Y.; Ma, B.; Xie, H.; Liu, W. Liquefaction of pretreated furfural residues. Biomass Chem. Eng. 2014, 48, 11-17. [CrossRef]

57. Ji, L.; Yu, H.L.; Liu, Z.P.; Jiang, J.X.; Sun, D.F. Enhanced ethanol production with mixed lignocellulosic substrates from commercial furfural and cassava residues. Bioresources 2015, 10, 1162-1173. [CrossRef]

58. Xing, Y.; Bu, L.; Sun, D.; Liu, Z.; Liu, S.; Jiang, J. Enhancement of high-solids enzymatic hydrolysis and fermentation of furfural residues by addition of Gleditsia saponin. Fuel 2016, 177, 142-147. [CrossRef]

59. Xing, Y.; Bu, L.; Zheng, T.; Liu, S.; Jiang, J. Enhancement of high-solids enzymatic hydrolysis of corncob residues by bisulfite pretreatment for biorefinery. Bioresour. Technol. 2016, 221, 461-468. [CrossRef]

60. Ji, L.; Zheng, T.; Zhao, P.; Zhang, W.; Jiang, J. Ethanol production from a biomass mixture of furfural residues with green liquor-peroxide saccarified cassava liquid. BMC Biotechnol. 2016, 16, 48. [CrossRef]

61. Li, Q.D.; Liu, B.; Zhuang, Q.Q.; Liu, T.J. Pretreatment, optimization of enzymatic hydrolysis and simultaneous saccharification fermentation of furfural residue. China Brew. 2018, 37, 115-120. [CrossRef]

62. Dong, J.-J.; Han, R.-Z.; Xu, G.-C.; Gong, L.; Xing, W.-R.; Ni, Y. Detoxification of furfural residues hydrolysate for butanol fermentation by Clostridium saccharobutylicum DSM 13864. Bioresour. Technol. 2018, 259, 40-45. [CrossRef] [PubMed]

63. Kan, T.; Strezov, V.; Evans, T.J. Lignocellulosic biomass pyrolysis: A review of product properties and effects of pyrolysis parameters. Renew. Sustain. Energy Rev. 2016, 57, 1126-1140. [CrossRef]

64. Huang, Y.; Wei, Z.; Yin, X.; Wu, C. Pyrolytic characteristics of biomass acid hydrolysis residue rich in lignin. Bioresour. Technol. 2012, 103, 470-476. [CrossRef]

65. Poletto, M.; Júnior, H.L.O.; Zattera, A.J. Thermal Decomposition of Natural Fibers: Kinetics and Degradation Mechanisms; John Wiley \& Sons, Inc.: Hoboken, NJ, USA, 2015.

66. Zhou, G.Z.; Hong, B. The research and development of furfural residue-fired circulating fluidized bed boiler. Ind. Boil. 2013, 15-19. [CrossRef]

67. Yang, X.D.; Zhang, D.K. The Study on Furfural Residue Biomass Briquette. Heilongjiang Environ. J. 2016, 40, 35-38. 
68. Qin, H.; Wang, W.; Liu, H.; Zhang, L.; Wang, Q.; Shi, C.; Yao, K. Thermal behavior research for co-combustion of furfural residue and oil shale semi-coke. Appl. Therm. Eng. 2017, 120, 19-25. [CrossRef]

69. Yin, Y.; Gao, Y.; Li, A. Self-activation of biochar from furfural residues by recycled pyrolysis gas. Waste Manag. 2018, 77, 312-321. [CrossRef]

70. Yue, F.; Pedersen, C.M.; Yan, X.; Liu, Y.; Xiang, D.; Ning, C.; Wang, Y.; Qiao, Y. NMR studies of stock process water and reaction pathways in hydrothermal carbonization of furfural residue. Green Energy Environ. 2018, 3, 163-171. [CrossRef]

71. Chen, L.; Zhou, J.B.; Zhang, Y.M.; Tian, L.; Ma, H.H.; Song, J.Z.; Zhang, Q.S. Re-utilization of furfural residues and wasted mushroom inoculation bags by multi-production gasification technology. Trans. Chin. Soc. Agric. Eng. 2017, 33, 231-236.

72. Molina, R.; Espinós, J.P.; Yubero, F.; Erra, P.; González-Elipe, A.R. XPS analysis of down stream plasma treated wool: Influence of the nature of the gas on the surface modification of wool. Appl. Surf. Sci. 2005, 252, 1417-1429. [CrossRef]

73. Wang, Q.; Hou, F.Y.; Sun, D.H.; Su, G.Q.; Sun, J. Study on the pyrolysis properties of furfural residue. J. Fuel Chem. Technol. 2004, 32, 230-234.

74. Quan, C.; Ma, Z.; Gao, N.; He, C. Pyrolysis and combustion characteristics of corncob hydrolysis residue. J. Anal. Appl. Pyrolysis 2018, 130, 72-78. [CrossRef]

75. Huang, Y.F.; Kuan, W.H.; Chiueh, P.T.; Lo, S.L. Pyrolysis of biomass by thermal analysis-mass spectrometry (TA-MS). Bioresour. Technol. 2011, 102, 3527-3534. [CrossRef]

76. Gao, N.; Li, A.; Quan, C.; Du, L.; Duan, Y. TG-FTIR and Py-GC/MS analysis on pyrolysis and combustion of pine sawdust. J. Anal. Appl. Pyrolysis 2013, 100, 26-32. [CrossRef]

77. Wang, Q.; Hou, F.Y.; Sun, D.H.; Cui, C.L.; Sun, J. Study on the characteristics and dynamics of pyrolysis process furfural residues. Acta Energ. Sol. Sin. 2004, 25, 750-754.

78. Wang, Q.; Sun, B.Z.; Liu, Y.; Hu, A.J.; Sun, J. Co-pyrolysis properties of furfural residue and rice husk blends. Trans. Chin. Soc. Agric. Eng. 2005, 21, 151-154.

79. Foo, K.Y.; Hameed, B.H. Porous structure and adsorptive properties of pineapple peel based activated carbons prepared via microwave assisted $\mathrm{KOH}$ and $\mathrm{K} 2 \mathrm{CO} 3$ activation. Microporous Mesoporous Mater. 2012, 148, 191-195. [CrossRef]

80. Ren, G.J.; Li, S.H. The Adsorption Performance of Furfural Residue for Menthylene Blue. Appl. Mech. Mater. 2012, 178, 433-436. [CrossRef]

81. Ren, G.J.; Wan, X.L. The Adsorption Performance of Furfural Residue for Plumbum Ion. Adv. Mater. Res. 2013, 826, 275-278. [CrossRef]

82. Sheng, J.; Ren, G.J.; Gao, X.R. Study on Adsorption of Methyl Violet from Aqueous Solution by Furfural Residue. J. Shenyang Ligong Univ. 2010, 29, 82-85.

83. Yang, K.; Peng, J.; Xia, H.; Zhang, L.; Srinivasakannan, C.; Guo, S. Textural characteristics of activated carbon by single step CO2 activation from coconut shells. J. Taiwan Inst. Chem. Eng. 2010, 41, 367-372. [CrossRef]

84. Wang, X.Y.; Li, D.X.; Yang, B.M.; Li, W. Textural Characteristics of Coconut Shell-Based Activated Carbons with Steam Activation. Adv. Mater. Res. 2013, 608, 366-373. [CrossRef]

85. Foo, K.Y.; Hameed, B.H. Utilization of rice husks as a feedstock for preparation of activated carbon by microwave induced $\mathrm{KOH}$ and $\mathrm{K} 2 \mathrm{CO} 3$ activation. Bioresour. Technol. 2011, 102, 9814-9817. [CrossRef]

86. Mao, X.; Kang, Q.; Liu, Y.; Siyal, A.A.; Ao, W.; Ran, C.; Fu, J.; Deng, Z.; Song, Y.; Dai, J. Microwave-assisted pyrolysis of furfural residue in a continuously operated auger reactor: Biochar characterization and analysis. Energy 2019, 168, 573-584. [CrossRef]

87. Chen, C.J.; Wei, L.B.; Zhao, P.C.; Li, Y.; Hu, H.Y.; Qin, Y.B. Study on Preparation of Activated Carbon from Corncob Furfural Residue with $\mathrm{ZnCl} 2$ by Microwave Irradiation. Adv. Mater. Res. 2011, 152, 1322-1327.

88. Zhang, C.L.; Xing, Q.; Ren, G.J. Preparation of modified fufural residue with epoxy chloropropane. Contemp. Chem. Ind. 2013, 42, 1222-1224. [CrossRef]

89. Ren, G.J.; Xing, Q.; Wang, X.P. Adsorption Performance of Modified Furfural Residue for Nickel Ion. Plat. Finish. 2013, 35, 44-46.

90. Wang, Y.; Xu, Z.Y.; Song, X.; Yang, B.; Zhang, D. The preparation of low-cost adsorbent for heavy metal based on furfural residue. Adv. Manuf. Process. 2017, 32, 87-92. [CrossRef] 
91. Chen, W.Y.; Cai, Y.C.; Sun, J.; He, Q. Acidic furfural residue pyrolysis experiments and pyrolytic carbon performance. Chem. Eng. 2017, 45, 5-10.

92. Chen, L.Z.; Xu, J.Z.; Jiao, Y.H. Advances on the preparation and applications of high adsorption activated carbons. Carbon Tech. 2014, 37-41. [CrossRef] 